\title{
Grammatical underpinnings of lexicalization patterns in Croatian, English and French: The case of [N PP] constructions
}

\author{
Daniela Katunar and Ida Raffaelli \\ University of Zagreb, Croatia
}

\begin{abstract}
This paper deals with the noun-preposition [N PP] construction in Croatian and compares the construction to its counterparts in English and French. Noun - preposition relations are analyzed as grammatical relations which participate in the formation of the lexicon, i.e. as grammatical devices which are productively used as lexicalization patterns. Based on the corpus analysis, [N PP] constructions in Croatian are identified and contrasted to English and French data. Lexical status of multi-word units in Croatian is discussed, as well as the level of idiomaticity of these constructions as compared to English and French. Whereas French and Croatian employ a similar lexicalization pattern, English uses compounding. The lexicon - grammar continuum is thus observed from the perspective of syntactic structures participating in word-formation.
\end{abstract}

Keywords: noun-preposition constructions, lexicalization patterns, Croatian, French, English

\section{Introduction}

Two processes typically associated with word-formation are derivation and compounding. This is especially common for analyses of morphologically rich languages such as Croatian, where various instances of multi-word units (e.g. bijela kava 'caffe latte; lit. white coffee', kava $s$ mlijekom 'macchiato; lit. coffee with milk') are considered to be highly idiomatic, omitted from overviews in grammars (e.g. Silić \& Pranjković, 2007) and generally viewed as belonging to the outskirts of the regular. Tafra (2005: 117-119) points out that lexicalization, a process which in the broad sense refers to the creation of new words and in the more narrow sense to reanalyzing groups of words as words themselves (multi-word units), is as much a syntactic as it is a morphological (i.e. word-formation) challenge. In other languages, such as French or English, the relevance of multi-word units in structuring the lexicon has been studied to a greater extent. Booij (2009a: 222) discusses such instances in Germanic, Greek and Romance languages under the term phrasal names, which he defines as types of phrases which share the naming function 
with complex words (2009a: 219). Similarly to Booij (2009a), Lyons (1995: 51) uses the term phrasal expressions when discussing lexically composite expressions and points out that such expressions are constructed using grammatical rules of a language. These rules include both morphological and syntactic devices used in the formation of the lexicon. Different grammatical devices that participate in the formation of the lexicon emphasize the long-term problem of uniformly defining the notion of the 'word' in linguistic theory, which is present from structuralist discussions onwards. ${ }^{1}$ Also, this problem is what drives contemporary theories of grammar, such as Construction Grammar, to argue for a continuum between lexicon and grammar, in large part based on the fact that grammatical rules or schemas play a significant role in building the lexicon, traditionally regarded as a repository of idiosyncratic forms. In this study we take the basic tenets of Construction Grammar (Goldberg 1995, 2006) as the theoretical and methodological background against which the $[\mathrm{N} \mathrm{PP}]$ construction is analyzed. More specifically, we consider the [N PP] construction as an instance of a more general grammatical relation (noun post-modification), but with a specific set of syntactic and semantic features which are pertinent to the process of lexicalization.

Thus the goal of this study is to investigate in greater detail the [N PP] construction ${ }^{2}$ in Croatian, e.g. Cro. četkica za zube 'toothbrush', odbojka na pijesku:Loc 'beach volleyball', alergija na mačke 'cat allergy', and contrast it to two typologically and genetically different languages - English and French. As we will show in our data, English and French differ with respect to their lexicalization strategies, i.e. productive morphosyntactic patterns used in comparison to Croatian. Most notably, English uses compounding as a productive grammatical device in word-formation, whereas French [N PP] constructions are considered to be a very productive lexicalization pattern. Instead of the term phrasal expression, we use the term [N PP] construction in order to emphasize the grammatical underpinnings of its lexical formation, in line with the aforementioned emphasis on the lexicon-grammar continuum. ${ }^{3}$ Moreover, the term points to one of its main properties of this type of construction. It is a particular lexicalization pattern with a specific naming function consistent with the criteria offered by Lyons (1995) and Booij (2009a).

There is little extant literature on the construction in Croatian, although generally authors view noun-preposition expressions as a grammatical phenomenon related to either noun modification (Silić \& Pranjković, 2007, Belaj \& Tanacković Faletar, 2014), complementation (Petrović 2016) or collocations (Blagus Bartolec 2014). The notion of construction used in this paper is broader than that of collocations because it places emphasis on the productivity of the syntactic pattern, as well as specific semantic and symbolic links that hold between nouns in the [N PP] construction. Furthermore, the emphasis is placed on the semantic (and/or functional) contribution of the preposition, a point that is omitted in extant overviews.

Raffaelli (2015) emphasizes the tendency of [N PP] patterns in Croatian towards lexicalization, especially drawing parallels to French examples, e.g. pomme de terre 'potato'. In

1 For example see Martinet's influential paper Le Mot (1966).

2 Note that this is different from the [N P N] construction as defined by Jackendoff (2008), e.g. day by day, dollar for dollar, book upon book.

3 This is also in line with Booij's (2009a: 237) notion of a constructional schema in his analysis of A+N phrases with a naming function. 
this respect the $[\mathrm{N} \mathrm{PP}]$ construction can be regarded as a type of lexicalization pattern i.e. a relation between meaning and surface expression, with the potential of being a typologically relevant pattern productive in the language (Talmy, 1985). The term lexicalization pattern is used mostly in connection to Talmy's work on the typology of lexicalization patterns of motion and location verbs (1985). The concept has been further expanded in Raffaelli and Kerovec (2017) to include word-formation patterns and other syntactic processes that are used in lexicalization of particular domains. Therefore, in the broad sense we consider as lexicalization patterns any arrangement of formal morphosyntactic elements with a specific meaning or function which can be observed contrastively.

The typological relevance of investigating this construction in Croatian is the motivation behind the contrastive analysis with English and French. We believe that such a tripartite contrastive analysis can have broader implications in examining grammatical processes in three large Indo-European language families - Slavic, Germanic and Romance - that represent a kind of regular and frequent lexicalization pattern used in naming certain semantic domains.

The main questions we will address in the paper are:

a) is the [N PP] construction productive in Croatian and what is its role in a morphologically rich language such as Croatian,

b) what lexicalization strategies are used in English and French as compared to Croatian as the source language,

c) what can a contrastive analysis reveal about the potential lexical status of Croatian [N PP] constructions,

With respect to lexicalization patterns, we must emphasize that we will use Croatian as a source language in our contrastive analysis. This means that we will expect different lexicalization patterns to emerge from our comparison to French and especially English, because it uses compounding more extensively than $[\mathrm{N} \mathrm{PP}]$ constructions.

\section{Noun - preposition relations in Croatian, English and French}

When it comes to investigating to role of prepositions in syntax and semantics, nounpreposition relations (of the $[\mathrm{N} \mathrm{PP}]$ type) can be viewed as secondary to verb-preposition relations, which are more often the focus of syntactic-semantic analyses in literature (e.g. Fillmore, 1968, 1977; Jolly, 1991; Rauh, 1993; Paillard, 2002; Katunar, 2015, Katunar \& Raffaelli, 2018). This is based on the view that in many languages without morphological cases, such as English and French, prepositions fill the role of cases in the argument structure of the sentence, with the verb at its centre. In syntactic-semantic analyses of prepositions in Croatian, prepositions are also commonly discussed in relation to case semantics, and are viewed as governing particular cases within the preposition phrase [PP]. For example, the expressions na stolu.Loc 'on the table', na stol.Acc 'on the table', sa stola.Gen 'off of/from the table' are defined as preposition-case constructions with the meaning of Location, Goal and Source, respectively. The prepositions na 'on' and $s(a)$ 'off (of)' add the spatial meaning of 'two-dimensional surface', in addition to the semantic roles coded by the entire preposition-case construction. Such analyses fall in line with the localist theories of cases and are also expanded by cognitive 
linguistic analyses of preposition semantics which view spatial meanings as the basis for extensions of non-spatial meanings as well, e.g. na Božić 'at Christmas'. ${ }^{4}$ However, these analyses often also rely on the broader sentence context to assess the meanings of prepositioncase constructions, such as those in (1) and (2), which is also centered around the verb and its argument structure, biti 'to be+location', staviti 'to put+goal'.

\section{(1) Knjiga je na stolu. \\ 'the book is on the table' \\ (2) Stavio sam knjigu na stol. \\ 'I put the book on the table'}

When it comes to noun-preposition relations, these are often analyzed as cases of noun modification or noun complementation, both processes being grammatical and not related to lexicalization. However, the distinction between complements and modifiers is not straightforward in the extant literature. In Croatian grammars (Silić \& Pranjković, 2007: 265) preposition phrases that follow nouns are modification phrases if they perform an attributive function, e.g. udžbenik na hrvatskom jeziku 'a textbook in Croatian', ples po kiši 'a dance in the rain', putovanje preko granice 'a voyage across the border'. They are considered atypical forms of modification because they depend on the relation of government instead of the typical relation of agreement present in the modifying Adjective-Noun constructions, e.g. mirno more 'calm sea'. Furthermore, examples of post-modification are usually facultative and semantically transparent. For instance, Belaj and Tanacković Faletar (2014: 184-186) give the following expression in (3) as an example of post-nominal modification:

\section{(3) mala lopta ispod stola.Gen}

'small ball under the table'

This pattern is interchangeable with other post-nominal modification phrases, e.g. mala lopta crvene boje.Gen 'small ball of red color', mala lopta iznad/preko puta stola 'small ball over/across from the table', i.e. it is fully transparent semantically and allows for facultative variability common for a productive grammatical schema. This is very similar to the way preposition phrases are viewed in English grammars, with PP being the most frequent post-modifier element in complex noun phrases (Biber et al., 1999: 606).

On the other hand, prepositional complements to nouns in Croatian ${ }^{5}$ are also discussed by Petrović (2016) as being facultative attributes with (mostly) weak government between the noun and preposition phrase, e.g. pozivnica za Tanju 'an invitation for Tanja', zaštita od/protiv hladnoće 'protection from/against the cold'. Another type of preposition complementation is given in Katunar (2015) and includes strong government which is often transferred from a specific verb-preposition relation, e.g. vjera u čovječanstvo 'belief in humanity' <vjerovati $u$ čovječanstvo 'to believe in humanity'. Due to the relation of strong government these constructions are not facultative, but also do not conform to the criteria of naming function.

\footnotetext{
4 See Pranjković (2002), Kerovec (2012), Belaj \& Tanacković Faletar (2014), Katunar (2015) and references therein.

5 As compared to German.
} 
Therefore, it is clear that the notions of government, complementation and modification are not strictly separated when it comes to many instances of noun-preposition relations. More importantly, the question of lexicalization of some of these expressions is not raised in such discussions.

However, it should be pointed out that in French linguistics Martinet (1989) analyzed with scrutiny the noun-preposition relation as a pattern used in formation of new linguistic expressions. It is well known that Martinet was an arduous critic of the notion and the term word in linguistics because of its inconsistency and theoretical incoherence. He considered it as not specific enough, especially when defined as a string of phonemes between two blanks on the paper. His comparison of the English lexeme ${ }^{6}$ potato and the French lexeme pomme de terre is well known. According to Martinet (1989), these linguistic units should both be considered autonomous syntagms. They both refer to the same referent, they share the same meaning, but in a structurally different manner. The lexeme pomme de terre is a linguistic unit representing a coherent syntagmatic structure and encoding a certain meaning. If one component (linguistic element) within the N PP structure would be replaced with another, e.g. the PP de terre 'lit. of the earth' with the adjective rouge 'red', the meaning of the syntagm pomme de terre would completely change. Instead of potatoes, we would have red apples (pomme rouge). Martinet argues for the term autonomous syntagm because it refers to different types of syntagmatic structures representing a coherent linguistic unit with respect to form and meaning. According to its typological features each language uses different linguistic elements and structures to form an autonomous syntagm. For example Croatian automobilom, French en voiture and English by car represent equal autonomous syntagms, but with different types of functional morphemes used. Croatian in this respect significantly differs from French and English, although the three expressions share the same meaning. Croatian uses the flective morpheme -om (encoding instrumental case), whereas French and English use prepositions en and by. For linguists it is important to recognize differences and similarities in linguistic elements used in structuring autonomous syntagms. It should be mentioned that Martinet already points out that linguistic units of the N PP type like brosse à dents, machine à laver represent a kind of classification of entities.

Therefore, what we consider to be the defining feature of lexicalization in the case of $[\mathrm{N}$ $\mathrm{PP}$ ] constructions is the naming function typical of phrasal names, e.g. gel za tuširanje 'shower gel', daska za rezanje 'chopping board', hokej na travi 'field hockey', čaj od mente 'mint tea'. The naming function should allow for an [N PP] expression to denote a class of entities, and not simply perform the function of a referential grounding of expression, as in (3) mala lopta ispod stola 'a small ball under the table'. Therefore, neither the complementation nor postmodification examples in the extant literature on Croatian are analyzed with regards to the naming function typical of phrasal names as part of the lexicon.

\footnotetext{
6 Note that Martinet (1989) does not use the term lexeme in the same sense as it is commonly used with respect to Anglo-Saxon tradition (see Raffaelli 2015).
} 


\section{Identifying [N PP] constructions in Croatian}

Lexicographic resources in Croatian offer scarce data on the $[\mathrm{N} \mathrm{PP}]$ construction and quite often do not list any of its instances as either separate lexical entries or possible idioms or collocations. This is unlike many multi-word units of the form Adjective-Noun, e.g. bijela kava 'caffe latte', crna rupa 'black hole', which are often listed as collocations (or syntagms). For instance, the entry četkica (četkica za zube 'toothbrush') is listed in two main monolingual dictionaries of Croatian, the online Croatian Language Portal ${ }^{7}$ and the Dictionary of Croatian Language (Šonje, 2000), only as a diminutive form of četka 'brush'. Therefore, in order to extract candidates for [N PP] constructions in Croatian we used the Croatian Web Corpus HrWaC, the largest general corpus of Croatian containing 1,9 billion tokens. Apart from some inconsistencies expected in large general dictionaries, the fact that the examples we extracted from corpora are not listed in those dictionaries may point to two important properties of the [N PP] construction. Firstly, it is behaving as an emergent lexicalization pattern and secondly, though the choice of the preposition phrase is fixed, it is omissible in some contexts (Raffaelli, 2015). For example, the following sentence in (4) is ambiguous without context.

\section{(4) ? Imamo različite vrste lakova \\ 'We have various types of polishes'}

However, in the extralinguistic context of a beauty parlor or a hardware store the noun lakovi 'polishes' could easily be inferred by the speaker to mean either lak za nokte 'nail polish' or lak $z a$ drvo 'wood polish', respectively. On the other hand, some expressions also vary in corpora between two types of modification patterns - [A N] and [N PP], e.g. dječji doplatak - doplatak $z a$ djecu 'childcare allowance, childcare benefit'. Dječji doplatak has 1929 occurrences in $\mathrm{HrWaC}$ ), and doplatak za djecu 600 occurrences. Though the frequencies surely point to the [A N] pattern as the dominant one, it is important to point out that in legislative documents (laws, administrative texts and official newspaper reports), i.e. those texts that define and control childcare benefits, the pattern is [N PP]. [A N] is mostly used in unofficial texts. In such cases it is important to note that corpus frequencies of particular [N PP] constructions may be skewed due to competing patterns. In many cases, however, it is not possible to use [A N] patterns at all, e.g. ${ }^{*}$ noktni lak 'nail polish', ${ }^{*} z u b n a$ četkica 'toothbrush'. Furthermore, in other cases $[\mathrm{A} \mathrm{N}]$ carries a different meaning and connotation than [N PP]. For example, azil za životinje means 'animal shelter. lit. asylum for animals', whereas životinjski azil 'lit. animalistic asylum' would carry the meaning 'animalistic, aggressive, crude' type of shelter.

Four of the most frequent primary prepositions in Croatian were chosen for the analysis ${ }^{8}$, $n a+$ Locative/Accusative 'on', $z a+$ Accusative/Instrumental 'for', od + Genitive 'from' and $s(a)$ + Genitive/Instrumental 'off of / with'.' Although prepositions are very frequent and

\footnotetext{
http://hjp.znanje.hr/

8 Though other primary and secondary prepositions were queried as well, e.g. ispod 'below', iznad 'above' etc.

9 Two other frequent morphologically simple prepositions were checked, $u+$ Accusative/Locative 'in' and $o+$ Accusative/Locative 'about'. These prepositions, however, did not yield any significant number of [N PP] constructions in our data.
} 
polysemous units, they can be regarded as the constant in the $[\mathrm{N} \mathrm{PP}]$ construction when it comes to corpus queries. We searched for all [N P N] sequences, and then manually extracted cases of $[\mathrm{N} \mathrm{PP}]$ constructions into a database based on our criteria mentioned above - naming a separate class of entities or phenomena.

The structure of the $[\mathrm{N} \mathrm{PP}]$ construction allows for some variation within the PP of two less frequent forms, [N P NN $\mathrm{GEN}_{\text {] }}$, e.g. aparat za gašenje požara.Gen 'fire extinguisher', and [N P [N i N]], e.g. dom za starije i nemoćne 'retirement home; lit. home for the elderly and feeble'. The latter instance is only found in the example 'retirement home'.

Table 1. below lists the number of different [N PP] constructions for each of the prepositions + cases we extracted from HrWaC. From a quantitative point of view, the frequencies would suggest it is a secondary lexicalization pattern when it comes to multi-word units, but still productive across various instances. However, the notion of the conventionalization of this pattern cannot rely solely on corpus frequency data, especially taking into account the types of entities being named, which are everyday basic objects, as we will show in the next section. Table 1. also shows the order of productivity of particular prepositions.

Table 1: Number of total occurences of [N PP] construction with a particular preposition extracted from $\mathrm{HrWaC}$.

\begin{tabular}{ll}
\hline Preposition + case & Number of [N PP] \\
\hline od + genitive & 769 \\
za + accusative & 446 \\
na + accusative & 114 \\
s(a) + genitive & 113 \\
na + locative & 58 \\
s (a) + instrumental & 21 \\
za + instrumental & 4 \\
\hline
\end{tabular}

\section{Some properties of [N PP] constructions in Croatian - domains, schematicity and specificity}

In order to get an insight into the types of entities being lexicalized by the [N PP] construction, i.e. its classificatory properties, we divided our data into domains. These domains are:

1) ARTEFACTS: četkica za zube 'toothbrush', aparat za kavu 'coffee machine', vreća za smeće 'garbage bag', perilica za rublje 'washing machine', palica za golf'golf club', palica za bejzbol 'baseball bat', papir za pečenje 'parchment paper, baking paper', polica za knjige 'bookshelf, čamac na vesla 'rowboat', ekran na dodir 'touch screen', dvorac od pijeska 'sand castle', škrinja s blagom 'treasure chest', ormarić s lijekovima 'medicine cabinet'

2) FOODSTUFF: salata od piletine 'chicken salad', čaj od mente 'mint tea', vrhnje za kuhanje 'heavy cream, cooking cream', sirup od bazge 'elderflower syrup', dagnje na buzaru 'mussells stew'

3) INSTITUTIONS: dom za djecu 'children's home, orphanage', agencija za zaštitu okoliša 'environmental agency', odjel za istraživanje 'department of research', klinika za traumatologiju 'trauma clinic'

4) ECONOMY and LAW: porez na dohodak 'income tax', jamac za kredit 'loan guarantor, loan cosigner', dozvola za rad 'work permit', doplatak za djecu 'childcare allowance'

5) MEDICINE: kapi za uši / oči / nos 'ear / eye / nose drops', sirup za kašalj 'cough syrup' 
6) SPORTS: odbojka na pijesku 'beach volleyball', četverac / dvojac na pariće 'quad / double scull', ronjenje na dah 'freediving'

7) SOCIO-CULTURAL RELATIONS: veza na daljinu 'long-distance relationship', lov na vještice 'witch hunt'

8) TITLES: Albert od Monaka 'Albert of Monaco'

The examples provided in these domains point to a notion of productivity not related to corpus frequency, but still relevant when it comes to discussing the saliency of [N PP] lexicalization pattern - the entities named are common objects, terms and activities which are found in everyday life and are culturally salient. Various artefacts - grooming implements, home appliances, foodstuff and medicines are some of the most basic items one can encounter. The domains we defined are of course broad domains of experience in general, and the [N PP] construction performs two specific functions when it comes to structuring parts of the lexicon: a) specialization of subordinate (hyponymy) members of a category and b) specification of polysemous or vague nouns.

a) The first function relies on the pronounced schematicity of this construction that allows for novel expressions to be made productively. It behaves as a periphrastic expression, being more semantically transparent than opaque. This is in part due to its grammatical form, but also it can be tied to what is known in Construction Grammar as an encoding idiom, an idiom whose meaning can be inferred from its parts but the speaker still would not know if it is the conventional way of saying something (Goldberg, 1995: 155). ${ }^{10}$ Goldberg gives the example of sofa bed which is in Croatian translated as kauč na razvlačenje.Acc and thus fits the description of encoding idioms quite well.

The schematicity in part accounts for the high frequency of some of the preposition + case combinations. For example, a significant part of [N PP] examples with the prepositions od + genitive refer to various sorts of food and drinks, and allow for specification of certain types of foodstuff via the prepositional phrase, as in (6), where various types of herbal tea are named by the same subpattern čaj od

(5)_čaj od__: borovnice / mente / bazge / jagode / kamilice / koprive...

'blueberry / mint / elderflower / strawberry / camomile / nettle... tea'

Such instances are usually subordinate members of a category (e.g. tea), and are present as hyponyms in the taxonomy. Therefore, [N PP] construction has a specialization effect of creating various co-hyponyms on the lower levels of taxonomy. This is pronounced in other examples as well, like many government agencies, kinds of taxes (income, property, estate tax and so forth). Interestingly, in higher levels of taxonomies, the [A N] pattern is usually the dominant one, as in Figure 1:

10 As Goldberg notes, this notion was first put forth by Makkai (1972). 


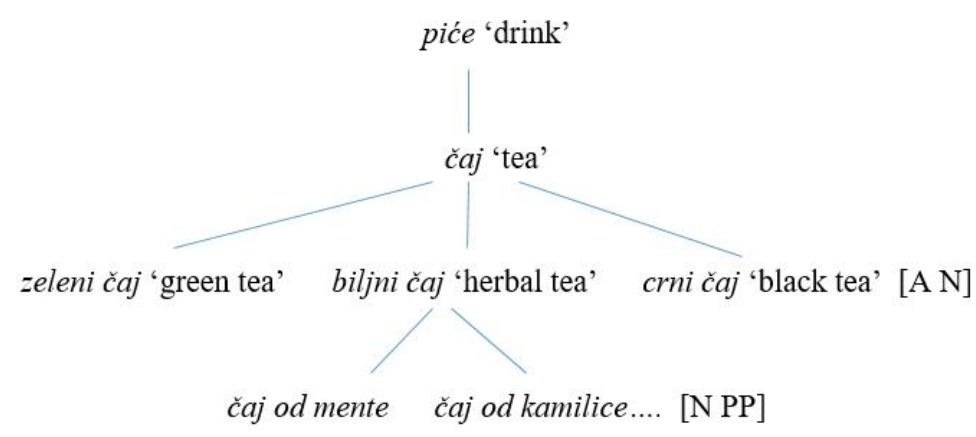

Figure 1: Lower levels of a taxonomy where [N PP] construction specifies "types of".

b) Secondly, there are many head nouns in our data which exhibit a type of vagueness. For example, daska 'board' can refer to a flat object, prototypically made from wood. However, the expressions daska za jedrenje 'windsurf board', daska za rezanje 'chopping board', daska za peglanje 'ironing board' all specify different objects with different functions and thus resolve the ambiguity. However, they cannot be treated as co-hyponyms because they belong to different categories - sports equipment, cooking tools, home equipment. Other nouns behave similarly, e.g. aparat za kavu 'coffee machine', aparat za dijalizu 'dialysis machine', aparat za gašenje požara 'fire extinguisher' - they all denote different types of machines with different functions.

The [N PP] construction can thus be analyzed as playing a part in two crucial areas of lexical structure - that of hierarchy relations and polysemy relations.

\section{Contrastive analysis of French and English to Croatian}

As we mentioned in previous sections, French and English use mutually different lexicalization strategies. In French there is a long tradition of regarding [N PP] constructions as an important part of the lexicon. In English, compounding is not reserved only for fixed expressions but is used productively and it is considered to form a subsystem of grammar as well (Jackendoff, 2009). In this way compounding is a way to produce lexically composite and novel expressions. The two languages examined together in comparison to Croatian reveal some interesting insights into the level of idiomatization of Croatian [N PP] constructions as well as their claim to lexical status.

The contrastive analysis was performed with Croatian data as the starting point. This means that $[\mathrm{N}$ PP] constructions collected from the Croatian corpus were translated into French and English and then particular patterns were examined.

\subsection{English and Croatian}

When it comes to English, the lexicalization strategy is predominantly compounding. The correlation between the lexicalization patterns is that the head noun N1 in Croatian corresponds to head noun N2 in English compounds, Cro. [N1 P N2] - Eng. [N2 N1] ${ }^{11}$, e.g.

\footnotetext{
11 We use the term head in line with the traditional definition that the head determines the syntactic and semantic category of a compound (Booij, 2009b), and in the case of Croatian, the syntactic and semantic category of the $[\mathrm{N} \mathrm{PP}]$ construction.
} 
vreća:1 za smeće:2 - garbage:2 bag:1, lak:1 za nokte:2 - nail:2 polish:1. The headedness of the two patterns thus reveals a grammatical consistency as well, both in word order and the semantics of the expressions. Furthermore, as English counterparts to Croatian examples can be found in dictionaries of English, such as the OED and Merriam Webster Online Dictionary, it is clear that Croatian [N PP] constructions acquire a lexical status of a sort. Interestingly, in the English-Croatian or Serbian Dictionary (Filipović, 1987) lexemes such as tooth-brush, nail polish and tooth-paste are translated as četkica za zube, lak za nokte and pasta za zube.

Another relevant observation relates to the status of prepositions in Croatian. While prepositions are considered to be on the border between lexical and functional words, it seems that their role in $[\mathrm{N} \mathrm{PP}$ ] constructions is highly grammaticalized and lacks the prototypical spatial semantics of these primary prepositions. For instance, the preposition na+Accusative profiles mainly MANNER, e.g. jaje na oko 'egg sunny-side up', čamac na vesla 'rowboat', ronjenje na dah 'freediving', lutka na napuhavanje 'love doll'. The preposition $z a+$ Accusative profiles mainly PURPOSE, e.g. daska za peglanje 'ironing board', gumica za brisanje 'eraser', pjena za brijanje 'shaving cream', UNDERGOER, e.g. perilica za rublje 'washing machine; lit. washer of laundry', lak za nokte 'nail polish' and BENEFICIARY kućica za psa 'doghouse', azil $z a$ životinje 'animal shelter'. ${ }^{12}$ Od+genitive 'from' is used for SOURCE MATERIAL, dvorac od pijeska 'sand castle', while s(a)+instrumental 'with' is used for containment/content for inanimates (škrinja s blagom 'treasure chest'). $\mathrm{Na}$ locative is the only element which still holds the spatial meaning in PPs, e.g. kućica na drvetu 'tree house, lit. house on the tree', but it is being reanalyzed as the integral part of the name of the entity. These roles are what the preposition phrase explicitly adds to an expression and are useful for naming properties which would not be explicitly named in cases of compounding or [A N] patterns. In English, on the contrary, such roles are usually inferred by the speakers from the compound form itself.

A few exceptions have to be noted as well. These have to do with two domains where instances of preposition phrases are found in the English data as well - institutions and titles, e.g. odsjek za lingvistiku - department of linguistics, centar za autizam - center for autism, Albert od Monaka - Albert of Monaco. However, these examples are scarce in the data and there are counterexamples in the same domains, e.g. klinika za traumatologiju - trauma clinic, trauma center. One correlation is with the descriptive of-construction and $z a+a c c u s a t i v e . ~ A n o t h e r$, between for and $z a+a c c u s a t i v e$ may be skewed due to Croatian being the starting point because some of the institutions are culturally specific and the English translation is adjusted to the original name in Croatian, e.g. agencija za mobilnost - agency for mobility. Another systematic correlation is with prepositions with and $s(a)+i n s t r u m e n t a l$. However, this is found in the subdomain of people with medical conditions, e.g. osobe $s$ invaliditetom - people with disabilities, and may have to do with the distancing the condition of the subject that the preposition with-s(a)+instrumental offers, for reasons of politeness and correctness.

English, therefore, with an abundance of compounds serving as equivalents to Croatian [N $\mathrm{PP}$ ] across all domains provides a good cross-linguistic argument for treating Croatian [N PP] constructions as instances of complex words, i.e. of phrasal names.

\footnotetext{
${ }_{12}$ Some of these are quite regular. For instance, $z a+$ Accusative with PURPOSE usually takes the gerund forms, i.e. deverbal nouns with the suffix -nje (jedrenje 'windsurfing', rezanje 'cutting').
} 


\subsection{French and Croatian}

When it comes to French, the N PP constructions are predominantly used in correspondence to Croatian N PP examples. However, there are some examples where French uses simple lexical units whit respect to Croatian N PP constructions such as cafetière : aparat za kavu 'coffee maker'; lessive: prašak za rublje 'detergent'; poubelle : koš za smeće 'trash bin'. This difference is mostly related to the artefact domain, with respect to which Croatian is very productive in using $\mathrm{N}$ PP constructions as a lexicalization pattern.

It should be pointed out that the two most frequently used prepositions in the French N PP constructions are $d e$ and $\dot{a}$. They are highly grammaticalized and therefore idiosyncratic, appearing in constructions referring to all the domains (except medicine), as defined for the Croatian N PP constructions. These are: artefacts - brosse à dents 'toothbrush', institutions maison de retraite 'retirement home' economy - permis de travail 'work permit', food - agneau à la broche 'lamb on a spit', sport - planche à voile 'sailboard', titles - Albert de Monaco. Regarding the domain of medicine, two prepositions that are systematically used in the French PP constructions are contre and pour, as in remède contre la toux / cancer / SIDA 'cough syrop / cure for cancer / AIDS', gouttes pour le nez 'nose drops'. In Croatian there is also a competing pattern with two antonymous prepositions: $z a+$ accusative 'for' and protiv+genitive 'against', used in the domain of medicine, e.g. sirup protiv kašlja - sirup za kašalj 'lit. syrup against/for the cough'. However, when the frequencies in HrWac were checked, sirup $z a N$ is twice as frequent than sirup protiv $N$ (382 versus 183 occurrences), for example. This shows that the purpose-oriented meanings of $z a+a c c u s a t i v e$ generalized in the $[\mathrm{N} \mathrm{PP}]$ construction.

Firstly, when comparing Croatian and French usage of the N PP constructions as kind of lexicalization pattern, one should note that the two languages exhibit a high degree of consistency in using the N PP constructions to lexicalize the same domains. Secondly, the French preposition $a$ corresponds to the usage of all the basic primary prepositions in the Croatian N PP constructions, such as na:Acc - lov na vještice - chasse aux sorcières 'witch hunt'; $z a: A c c$ - perilica za rublje - machine à laver 'washing machine'; na:Loc-janjac na žaru - agneau à la broche 'lamb on a spit'; s(a):Instr - škrinjica s blagom - coffre au trésor 'tresaure chest'. Therefore, $d e$ and $a$ are more grammaticalized and idiosyncratic than Croatian PPs in the sense that the particular semantic import from the preposition is not as predictable as it is in Croatian. However, it should be pointed out that od:Gen is the only Croatian primary preposition which systematically corresponds to the French preposition de: kora od banane-poile de banane 'banana peel'. When the PP refers to a material of which a certain item is made of as in haljina od svile 'silk dress', nakit od srebra 'silver jewellery', the French preposition en is systematically used as in robe en soie, bijoux en argent.

Furthermore, the comparative analysis of Croatian and French N PP constructions shows that in both languages the N PP constructions cover the same range of semantic domains, and thus should be considered as a frequent and highly entrenched lexicalization pattern. It means that the cross-linguistic analysis of the same grammatical structure - the N PP construction could point to some frequent and regular grammatically underpinned strategies speakers use in lexicalization, i.e. naming certain items. From the lexical-semantic point of view, these 
constructions share the same classification principle. They all represent hyponyms within taxonomic lexical structures, which also points to their highly corresponding regular features.

\section{Conclusion}

The results of the analysis of [N PP] constructions in Croatian as compared to English and French reveal a grammatically based noun-preposition relation being used in the service of lexicalization. The main properties of the [N PP] construction, specialization of hyponymy relations and specification of vagueness, make it an essential part of lower levels of the lexicon hierarchy, both in Croatian and in French. The contrastive analysis showed that English and French differ systematically in their lexicalization strategies, with English using compounding extensively in the place of [N PP]. Moreover, the analysis shows that Croatian and French frequently and regularly use the corresponding grammatically underpinned strategy to lexicalize the same semantic domains. The analysis points to the model of lexicalization patterns as typologically relevant capturing diverse grammatical structures being productive in the process of lexicalization. Such an examination of corresponding lexicalization patterns interand intra-linguistically lays the ground for future comparisons and establishes a theoretical framework for examining the relationship between lexicalization, grammaticalization and idiomatization.

\section{References}

Biber, D., Johansson, S., Leech, G., Conrad, S., Finegan, E., \& Quirk, R. (1999). Longman grammar of spoken and written English (Vol. 2). Cambridge, MA: MIT Press.

Blagus Bartolec, G. (2014). Riječi i njihovi susjedi. Kolokacijske sveze u hrvatskom jeziku. Zagreb: Institut za hrvatski jezik i jezikoslovlje.

Booij, G. (2009a). Phrasal names: A constructionist analysis. Word Structure, 2(2), 219-240.

Booij, G. (2009b). Compounding and construction morphology. In R. Lieber \& P. Stekauer (Eds.), The Oxford Handbook of Compounding (201-216). Oxford: Oxford University Press.

Belaj, B., Tanacković Faletar, G. (2014). Kognitivna gramatika hrvatskoga jezika, Knjiga prva, Imenska sintagma i sintaksa padeža. Zagreb: Disput.

Fillmore, Ch. J. (1968). The case for case. In E. Bach, Th. Harms (Eds.), Universals in Linguistic Theory (1-88). New York: Holt, Rinehart, and Winston.

Fillmore, Ch. J. (1977b). The case for case reopened. Syntax and semantics(8), 59-82.

Goldberg, A. E. (1995). Constructions: A Construction Grammar Approach to Argument Structure. Chicago: University of Chicago Press.

Goldberg, A. E. (2006). Constructions at work: The nature of generalization in language. Oxford: Oxford University Press.

Jackendoff, R. (2008). 'Construction after Construction' and Its Theoretical Challenges. Language, 8-28. Jackendoff, R. (2009). Compounding in the Parallel Architecture and Conceptual Semantics. In R. Lieber \& P. Štekauer (Eds.) The Oxford Handbook of Compounding (105-128). Oxford: Oxford University Press.

Jolly, J. (1991). Prepositional analysis within the Framework of Role and Reference Grammar. New York: Peter Lang. Katunar, D. (2015). Ustroj leksikona u konstrukcijskoj gramatici - primjer prijedloga u hrvatskom jeziku. Unpublished PhD thesis. Zagreb: Filozofski fakultet. 
Katunar, D. \& Raffaelli, I. (2018). Contrastive study of governed prepositions in Croatian, English and French. In P. Biały \& B. Cetnarowska (Eds.) Studies in Contrastive Semantics, Pragmatics and Morphology (55-70). Katowice: Wydawnictwo Uniwersytetu Śląskiego.

Kerovec, B. (2012). Kognitivnolingvistička analiza prostornih odnosa u turskom i hrvatskom jeziku. Unpublished $\mathrm{PhD}$ thesis. Zagreb: Filozofski fakultet.

Lyons, J. (1995). Linguistic Semantics: An introduction. Cambridge: Cambridge University Press.

Makkai, A. (1972). Idiom structure in English (Vol. 48). The Hague: Walter de Gruyter.

Martinet, A. (1966). Le mot. Problèmes du langage. Paris: Gallimard. 39-53.

Martinet, A. (1989). Fonction et dynamique des langues. Paris: Armand Colin.

Paillard, D. (2002). Prépositions et rection verbale. Travaux de linguistique(1), 51-67.

Petrović, V. (2016). Imenske skupine s prijedložnim komplementima u njemačkom i njihovi ekvivalenti u hrvatskom jeziku. Jezikoslovlje 17(1-2), 207-234.

Pranjković, I. (2002). Hrvatska skladnja: Rasprave iz sintakse hrvatskoga standardnog jezika, drugo, izmijenjeno izdanje. Zagreb: Hrvatska sveučilišna naklada.

Raffaelli, I. (2015). O značenju. Uvod u semantiku. Zagreb: Matica hrvatska.

Raffaelli, I. \& Kerovec B. (2017). The concept of 'taste' in formation of Croatian and Turkish lexicon: A contrastive analysis. Suvremena lingvistika(83). 21-48

Rauh, G. (1993). On the grammar of lexical and non-lexical prepositions in English. In C. Zelinsky Wibbelt (Ed.). The Semantics of Prepositions: From mental processing to Natural Language Processing (99 - 151). Berlin, New York: Mouton de Gruyter.

Silić, J. \& Pranjković, I. (2007). Gramatika hrvatskog jezika za gimnazije i visoka sveučilišta. Zagreb: Školska knjiga. Tafra, B. (2005). Od riječi do rječnika. Zagreb: Školska knjiga.

Talmy, L. (1985). Lexicalization patterns: Semantic structure in lexical forms. Language typology and syntactic description, 3(99), 36-149.

\section{Dictionaries}

Filipović, R. (2004). Englesko-hrvatski rječnik. Zagreb: Školska knjiga.

Hornby, Albert Sydney, \& Sally Wehmeier (1995). Oxford advanced learner's dictionary. (Vol. 1428). Oxford: Oxford University Press.

LEXILOGOS: http://www.lexilogos.com/english/french_dictionary.html

Šonje, Jure. (2000). Rječnik hrvatskoga jezika. Zagreb: Leksikografski zavod Miroslav Krleža i Školska knjiga.

Hrvatski jezični portal, Novi Liber, SRCE, http://hjp.znanje.hr/ 